\title{
Vehicle Impacts on Northern Great Plains Range Vegetation
}

\author{
GENE F. PAYNE, AND JOHN W. FOSTER, AND WA YNE C. LEININGER
}

\begin{abstract}
Three levels of vehicle impact $(2,8,32$ trips over the same tracks) were applied on rangelands near Ashland, Mont., using a fourwheel-drive Chevrolet Blazer with mud and snow radial tires. The impacts were applied each month, May to September, on previously unimpacted range. Canopy coverage measurements and ground and aerial photography were used to evaluate the impact effects. In the year of impact, canopy coverage measurements showed Increasing damage to the vegetution as the number of trips increased. Damage was greater on very moist to wet soils than on dry soils. Vegetation measurements the year following the impacts did not show carry-over damage to vegetation from the 2 and 8 trip treatments, except for range impacted when the soils were wet. These measurements did show carry-over damage to shrubs from 32 trips, but not to grasses and forbs. Ground and aerial photographs in the first year after the impacts still showed visual evidence of 8 and 32 trip impacts. Aerial photographs taken the second year after the impacts still showed evidence of all 32 trip treatments and some 8 trip treatments. Color infrared film gave superior results when the vegetation was actively growing. Color film was superior when the vegetation had dried.
\end{abstract}

Off-road vehicle (ORV) travel has become a major concern of federal and state land management agencies and many ranchers. Limited research on vegetational impact from ORV's has been done in the deserts of the Southwest and along both eastern and western coastlines, but none has been done in the Northern Great Plains. A great deal of work has been done on the effects of agricultural and military vehicles on soils, but comparatively little literature is available on ORV-rangeland relationships.

The military has done exhaustive studies using aerial photography to assess vehicle impacts on vegetation. Unfortunately, only part of this work is available to the research scientist. Still, there is a wealth of other information available dealing with the photography of vegetation. (See footnote).

Our primary objectives were to (1) determine the effects of vehicle impacts on soil and vegetation and (2) evaluate photography as a means of identifying vehicle impact.

\section{Study Area}

The study area is $13 \mathrm{~km}$ northeast of Ashland, Mont., on the Ashland District of the Custer National Forest. The soils on the site are predominantly clay loams with some silty clay loams. The area has a continental climate with precipitation occurring primarily during April, May, and June. The vegetation is mixed upland prairie and is dominated by crested wheatgrass (Agropyron crista-

\footnotetext{
Authors are professor emeritus of range sciences, Montana State University, BozeAuthors are professor emeritus of range sciences, Montana State University, Boze-
man 59717; supervisory range conservationist, BLM, Taos, New Mexico 87571; and research assistant, Oregon State University. Corvallis 97331 . This article is based on Mr. Foster's M.S. thesis and the second year field work done by Mr. Leininger (MAES Research Report 153).

The detailed literature review section of the thesis by Foster (1977) may be obtained from the Department of Animal and Range Sciences, Montana State University, Bozeman 59717.

This research was partially supported by grants from the Custer National Forest, U.S.F.S. We appreciated the cooperation of Ashland Ranger District personnel. particularly District Ranger Charles McGlothlin.

This is MAES journal article series No. 1209.

Manuscript received September 8, 1981.
}

tum), western wheatgrass (Agropyron smithii). Junegrass (Koeleria pyramidata), yellow sweetclover (Melilotus officinalis), and big sagebrush (Artemisia tridentata). The crested wheatgrass was interseeded into the native vegetation in 1957.

Other major species include bluebunch wheatgrass (Agropyron spicatum), blue grama (Bouteloua gracilis), western yarrow (Achilla millefolium), and plains prickly pear (Opuntia polyacantha).

The vegetational composition, on a canopy coverage basis, averaged $60 \%$ grasses and sedges ( 25 species), $20 \%$ forbs ( 42 species), and $20 \%$ shrubs (11 species). Total vegetation canopy cover ranged from $34 \%$ in May to $72 \%$ in June and $67 \%$ in September.

Yellow sweetclover was much more common on the south slopes of the experimental area. The crested wheatgrass, largely restricted to the north slope, was interspersed with the native vegetation but was prominent in the general vegetational aspect.

Livestock had free access to the area during the summer grazing period.

\section{Methods}

Impact treatments were applied in 1976 followed by soils and vegetational studies. No treatments were applied in 1977, but several of the 1976 evaluations were repeated in June and August.

A four-wheel drive Chevrolet Blazer with mud and snow radial tires was driven 2 times in one track, 8 times in one track, and 32 times in one track, up and down gentle north and south slopes $(6-8 \%)$ and across the connecting ridgetop. These impact treatments were applied on adjacent strips of rangeland about the 15 th of the month, May through September, 1976, using previously unimpacted rangeland strips each month. The phenologies of the major species at the times of treatment are shown in Table 1. Control (no ORV impact) strips were included in the design. The statistical model was a strip plot with split-split block superimposed.

Soil surface compaction was measured with a pocket penetrometer (Model CL-700, Soil Test IUC., Chicago, Illinois).

Soil cracking occurred in the clay soils as they dried in the summer. Crack orientation and depths were measured to determine whether or not vehicle impact influenced cracking characteristics.

Soil water was measured gravimetrically to a $15 \mathrm{~cm}$ depth and with a neutron probe to $122 \mathrm{~cm}$ the first year. No soil water measurements were taken the second year.

Soil bulk density measurements (first year only) were made on samples from the $0-7.6 \mathrm{~cm}$ and $7.6-15.2 \mathrm{~cm}$ levels.

Infiltration rates (first year only) were tested on soil cores 5.08 $\mathrm{cm}$ in diameter and $15 \mathrm{~cm}$ deep taken into the laboratory. The technique was that described by Richards (1969) as modified earlier by Phillip (1957, 1958).

Vegetational canopy cover estimates were made following the method described by Daubenmire (1959). Twenty-five plots were taken in each treatment (travel date $\times$ trip treatment). Cover data were taken immediately after the impacts, 1 month following impacts, at the end of the 1976 season and in June and August of 1977. 
Table 1. Phenological stages of vegetation at the times of ORV impact, about the middle of each month.

\begin{tabular}{|c|c|c|c|c|c|}
\hline & May & June & July & August & September \\
\hline Crested wheatgrass & Boot & $\begin{array}{c}\text { Fruit } \\
\text { formed }\end{array}$ & $\begin{array}{c}\text { Seed } \\
\text { shatter }\end{array}$ & $\begin{array}{l}\text { Seed } \\
\text { shatter }\end{array}$ & Dormancy \\
\hline Bluebunch wheatgrass & Vegetative & $\begin{array}{l}\text { Fruit } \\
\text { formed }\end{array}$ & $\begin{array}{c}\text { Seed } \\
\text { shatter, } \\
\text { dormancy }\end{array}$ & $\begin{array}{l}\text { Dormancy, } \\
\text { leaf drop }\end{array}$ & $\begin{array}{l}\text { Dormancy, } \\
\text { leaf drop }\end{array}$ \\
\hline Western wheatgrass & Vegetative & $\begin{array}{c}\text { Fruit } \\
\text { formed }\end{array}$ & $\begin{array}{c}\text { Seed } \\
\text { shatter }\end{array}$ & $\begin{array}{c}\text { Seed } \\
\text { shatter }\end{array}$ & $\begin{array}{l}\text { Dormancy, } \\
\text { leaf drop }\end{array}$ \\
\hline Blue grama & Vegetative & Anthesis & $\begin{array}{c}\text { Fruit } \\
\text { formed }\end{array}$ & $\begin{array}{c}\text { Seed } \\
\text { shatter }\end{array}$ & $\begin{array}{l}\text { Dormancy, } \\
\text { leaf drop }\end{array}$ \\
\hline Junegrass & Boot & $\begin{array}{l}\text { Fruit } \\
\text { formed }\end{array}$ & $\begin{array}{c}\text { Fruit to } \\
\text { seed shatter }\end{array}$ & $\begin{array}{l}\text { Seed } \\
\text { shatter to } \\
\text { dormancy }\end{array}$ & $\begin{array}{l}\text { Dormancy, } \\
\text { fall growth }\end{array}$ \\
\hline Sweetclover & Vegetative & $\begin{array}{l}\text { Early } \\
\text { flowering }\end{array}$ & $\begin{array}{l}\text { Late } \\
\text { flowering }\end{array}$ & $\begin{array}{l}\text { Seed } \\
\text { shatter, } \\
\text { leaf drop }\end{array}$ & $\begin{array}{l}\text { Dormancy, } \\
\text { fall growth }\end{array}$ \\
\hline Big sagebrush & Vegetative & Vegetative & $\begin{array}{l}\text { Flower } \\
\text { buds }\end{array}$ & Flowering & $\begin{array}{l}\text { Late flowering, } \\
\text { fruit forming }\end{array}$ \\
\hline
\end{tabular}

Plant phenology information was taken according to the system used by Taylor et al. (1975).

Color infrared and color print photography were used on the ground the first year to follow gross vegetational changes occurring during the growing season. Also during the first year, the site was monitored monthly by aerial photography at scales ranging from 1:3,000 to $1: 12,000$ using both color infrared and color print films in $70 \mathrm{~mm}$ format. The area was aerially photographed 3 times the second year (1977) with the first and last flights coinciding with ground sampling. Aerial photographs were again taken in June, 1978. The film types used were Kodak Vericolor II 6010 for color print and Ektachrome Aero 2443 for color infrared. All photos were interpreted visually.

\section{Results and Discussion}

Soils

In 1976, the year of treatment, soil water in non-impacted (control) soils varied from $19 \%$ in June to $2.6 \%$ in August. When the data by months were averaged by treatment, percentage water values were:

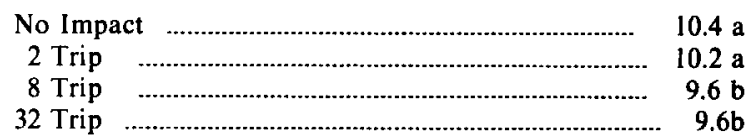

Values with the same letter are not significantly different at the $P=.05$ level.

Although Duncan's multiple range test indicated significant differences, the differences were relatively small.

Bulk density showed some tendency to increase as the number of trips increased at the May and June dates when soil water was higher. However, these differences were not statistically significant except for the 32-trip treatment. There was an increase in bulk density with soil drying, unrelated to treatment.

Penetrometer measurements were more sensitive to the effects of ORV impact than bulk density measurements. The lowest penetrometer readings (least resistance to the penetrometer) were on nonimpacted soils in May and June at $1.56 \mathrm{~kg} / \mathrm{cm}^{2}$. Penetrometer readings on the May and June impacted soils increased with travel to highs of $3.96 \mathrm{~kg} / \mathrm{cm}^{2}$ and $4.39 \mathrm{~kg} / \mathrm{cm}^{2}$ for the 32-trip treatment.

The July impacts also caused increasing penetrometer readings as the number of trips increased: $1.79 \mathrm{~kg} / \mathrm{cm}^{2}$ on nonimpacted soils to $3.67 \mathrm{~kg} / \mathrm{cm}^{2}$ for 32 trips.

August and September impacts had a reverse effect. Nonimpacted soils had the highest penetrometer readings, $3.19 \mathrm{~kg} / \mathrm{cm}^{2}$. The penetrometer readings for the impacted soils ranged from an average of $2.24 \mathrm{~kg} / \mathrm{c.}^{2}$ for 2 trips to $2.74 \mathrm{~kg} / \mathrm{cm}^{2}$ for 32 trips.
Impacting soils when they are dry develops a thin layer of loose dust, thus reducing the penetrometer resistance.

Penetrometer reading were again taken in 1977 in June and August. The soils were very moist in June and moderately dry in August. A summary of the treatment level data $\left(\mathrm{kg} / \mathrm{cm}^{2}\right)$ showed:

\begin{tabular}{lcccc} 
Test Month & \multicolumn{4}{c}{ Trips } \\
1977 & 0 & 2 & 8 & 32 \\
June & $2.05 \mathrm{a}$ & $2.21 \mathrm{a}$ & $2.52 \mathrm{~b}$ & $2.67 \mathrm{~b}$ \\
August & $1.99 \mathrm{a}$ & $2.13 \mathrm{a}$ & $2.61 \mathrm{~b}$ & $2.89 \mathrm{c}$
\end{tabular}

Row values with the same letter are not significantly different at the $P=.05$ level.

Obviously, the effect of 8 trips and 32 trips in 1976 carried over into 1977. Although the averages for 2 trips were not significantly higher statistically than for nonimpacted soils, they did fit the pattern of increasing penetrometer resistance with increasing travel over the same tracks.

It also is well to note that the differences in 1977 were smaller when soil was moist (in June) than when it was dry (in August).

The increasing penetrometer resistance from 0 to 32 trips appears to contradict the August and September, 1976, data discussed above. It must be remembered, however, that the thin layer of dust present in 1976 was not present in 1977, allowing the 1976 impact on the soil under the dust to contribute in 1977 to the increasing penetrometer resistance as trips increased.

The fact that the penetrometer provided a reasonably sensitive indicator of ORV impact while bulk density did not implies that: (1) the methodology used in measuring bulk density was inadequate; (2) the compacting effect was limited to a very thin $(3 \mathrm{~cm}$ or less) soil surface layer; (3) the effect of moisture on bulk density measurements over-shadowed effect of impact from the vehicle wheels; or (4) some combination of these factors affected the value of bulk density as an indicator of wheel impact. The literature on the subject (e.g. McLeod 1966, Vanden Berget al. 1957, Liddle and Grieg-Smith 1975, Dotzenko et al. 1967) indicates the bulk density methodology in this study to be the problem.

Figure 1 shows the effects of ORV impact on infiltration for 2 of the 5 months. The soils were very moist in June and dry in August. The 32-trip impact was clearly detrimental to infiltration in all months. The 2-trip and 8-trip impacts did not differ significantly from each other in any month in their effects on infiltration. These 2 impact levels in May, July, and September had the approximate relationship shown in the August graph.

One of the potentially troublesome consequences of ORV impact on moist soils was the development of cracks oriented along the wheel tracks as the soils dried. Non-impacted soils had cracks but they were not oriented in any particular direction. 


\section{JUNE IMPACT}

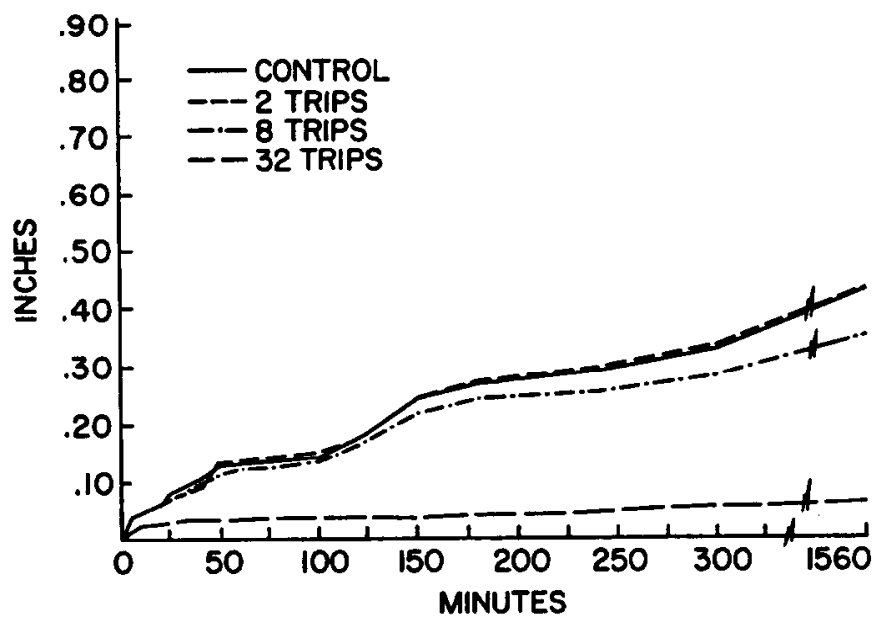

AUGUST IMPACT

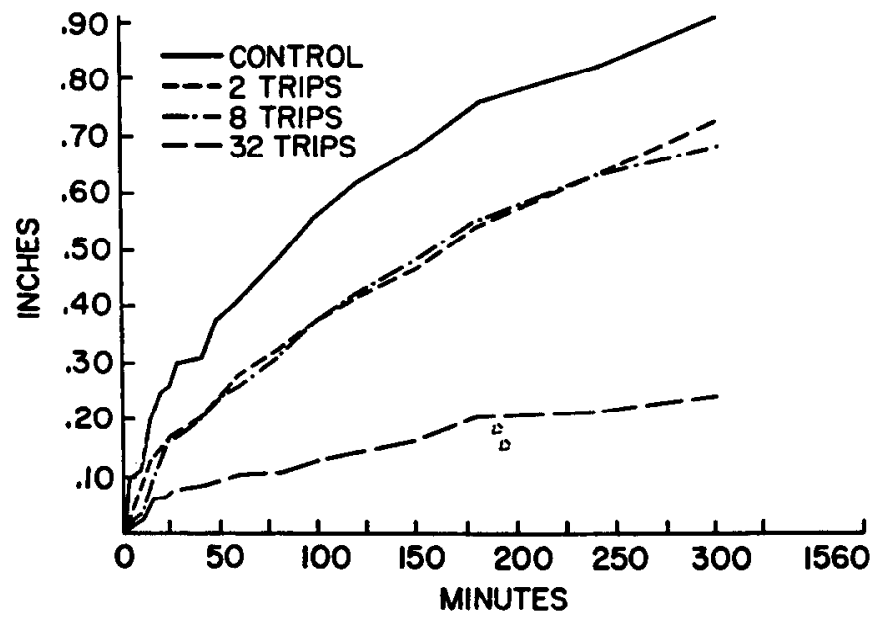

Fig. 1. Infiltration rates resulting from four levels of ORV impact in June and August, 1976.

In 1976, May impacted soils showed the following soil crack depths when they had dried in late summer:

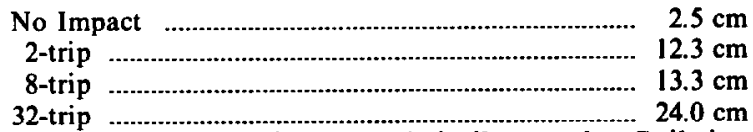

The June impacted soils showed similar results. Soils impacted when they were dry (July, August, September) did not exhibit the "wheel track crack" phenomenon.

In 1977, there was little soil cracking noted in the June analysis; however, cracks had developed by August in the May 1976 impacted soils with the following depths:

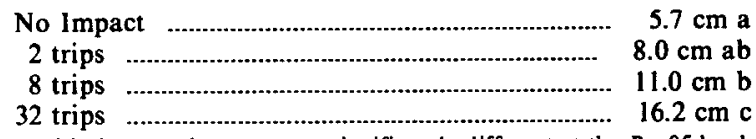

Values with the same letter are not significantly different at the $P=.05$ level.

The June impacted soils showed similar results. Soils impacted when they were dry (July, August, September) did not exhibit the "wheel track crack" phenomenon.

Again, the cracks in the nonimpacted soils were in many directions, while the cracks in the impacted soils followed the direction of the wheel tracks.
It is possible that the soil cracks developed in wheel tracks could be the genesis of serious erosion problems if rainfall came in heavy amounts when the cracks were widest and deepest along the wheel tracks.

None of the soil impacts were influenced significantly by north vs. south exposures or by uphill vs. downhill travel.

The June treatment resulted in some wheel ruts in the wet soils. These ruts could be the origin of erosion channcl problems (Hill and Kirby 1948).

\section{Vegetation}

Plant development for the major species at the five impact treatment dates is shown in Table 1. Major growth had taken place by the mid-June treatment date, with some growth continuing into July. Fall growth began prior to the mid-September treatment date.

An interesting problem arose in measuring canopy cover in 1976. ORV impacts crushed some vegetation, particularly the grasses, to a more horizontal position but did not break off the stems. This expanded the polygons (per canopy coverage method) of live vegetation, sometimes resulting in higher canopy coverage values for impacted vegetation than for the nonimpacted vegetation. Some of the crushed vegetation regained its upright stature within a week or two. Some clearly was dead. Because of these problems, canopy cover sampling taken immediately after impact was divided into cover of "affected," or crushed, vegetation and "unaffected', not crushed, vegetation. Later evaluation of these data raised questions as to their value in assessing ORV impacts.

The vegetation was sampled again 1 month after the first sampling (except for the September impact), but without separating the plants into the "affected" and "unaffected"categories. In retrospect, these data were considered more indicative of ORV impact than the data taken immediately after the impact, and are the basis for the following evaluations of the 1976 vegetation responses to OR V impact.

The most useful vegetation data, however, appear to be those taken 1 year later, 1977. These data were completely free of the cover measurement problems discussed above and reflect more than temporary damage to the vegetation.

\section{6}

The data taken 1 month after impact revealed losses in canopy coverage of grasses generally to be greatest from the July impacts and least from the May impacts. Grass growth between the May treatment and its June measurement obscured some of the initial damage. The same is true to a lesser degree from the June treatment to its July measurement.

The lowest canopy coverage losses of grass were from the 2-trip impact. The highest losses were from the 32-trip impact. The 8-trip impact gave losses generally approaching or about equal to the 32-trip impact. Percentage loss values among treatment replications, compared to nonimpacted grass canopy, ranged from less than $1 \%$ in a 2-trip treatment to $99 \%$ in a 32-trip treatment.

Forb canopy cover values in this vegetation were low: $1.7 \%$ in May to $4.6 \%$ in August, nonimpacted. As a result, the sampling was inadequate for this group of plants and none of the differences were statistically significant. Nevertheless, we feel we can make some general statements about the ORV impacts on forbs. May and June impacts appeared to be less damaging than later impacts. The loss with 2 trips was below 5\% for May and June. Losses in these 2 months for the 8-trip and 32-trip impact replications were higher, going up to more than $80 \%$. The losses of forb cover in later months ranged from $40 \%$ to $90 \%$, with the 2-trip losses only moderately lower than the 8 and 32-trip impacts.

Shrub cover on nonimpacted range varied from $6.6 \%$ in May to $15 \%$ in September (19-22\% of the total vegetational cover). Again, many of the differences among treatments, including nonimpacted, were not statistically significant. The data indicated increasing damage from May through September at each impact intensity. The data also showed generally increasing da mage as the number of impacts increased. The lowest shrub cover loss 
(impacted compared to nonimpacted) was $5 \%$ for 2 trips in May. The highest was $100 \%$ for 32 trips in August.

\section{7}

The grasses did not show any undesirable carry-over effects of the 1976 impacts. In fact, the 1977 data showed $2-4 \%$ higher cover of grasses on all levels of 1976 impacted range than on nonimpacted range. These differences were not statistically significant.

Some minor differences in forb cover among 1976 impact dates and intensities were found in the June sampling in 1977. These differences were no longer present in the August sampling.

Impact effects on shrub canopy cover in 1976 carried over into 1977. Shrub cover loss in 1977 was lowest on the May, 1976 impacts $(8 \%)$ and highest on the September impacts (12\%). The May and September values were significantly different statistically. The June, July, and August values were intermediate and generally not significantly different from either the May or September values.

\section{Bare Ground}

The amount of bare ground on the nonimpacted range remained about the same, 30-35\%, June through August and 5 to $8 \%$ lower in September.

Two and 8 trips in May did not significantly affect the amount of bare ground compared to nonimpacted range, but 32 trips increased bare ground to $52 \%$.

The 2 and 8-trip impacts in June showed small increases over the bare ground on nonimpacted range. The 32-trip impact averaged $45 \%$ bare ground, higher than nonimpacted range but lower than the 32-trip impact in May.

On the July impacted range, bare ground was slightly lower with the 2-trip impact than with no impact. The 8-trip impact had $42 \%$ bare ground compared to $32 \%$ on nonimpacted range, while $32-$ trips had the same amount of bare ground as the nonimpacted range.

Bare ground on nonimpacted range had dropped to $25 \%$ by September. The 2-trip impact in August showed $16 \%$ bare ground in September. The 8-trip bare ground was $28 \%$ and the 32 -trip bare ground figure was $55 \%$.

Field observations helped in the interpretation of the above figures. The nonimpacted range did not change much until the September reading, when bare ground was lower. This reduction was due to the addition of newly cured vegetational material to the mulch layer.

In the May impacts, very little vegetational material was added to the mulch, but as the number of trips increased, the residual mulch was increasingly pulverized and no longer recognizable. Thus, the 32-trip treatment had the most bare ground.

There was more vegetation present by June, with greater addition of vegetational material to the mulch layer through the ORV impact. This added material was more resistant to pulverization than the old mulch. The 2-trip and 8-trip impacts apparently added about as much new material to the mulch layer as they dest royed by pulverization of old mulch, so the amount of bare ground was less than on the May impacted range.

Even more current growth was present by July and the 2-trip impact added more material than it pulverized, resulting in less bare ground than on the nonimpacted range. Eight trips apparently pulverized a little more mulch than they added, but the 32-trip impact appeared to add as much mulch material as it pulverized.

By the August impact date, the vegetation was mostly mature and dry. Again, 2 trips added considerably more to the mulch layer than it destroyed and bare ground was much lower than on nonimpacted range. Eight trips destroyed more than was added, with $38 \%$ bare ground compared to $25 \%$ on nonimpacted range. The 32-trip impact was even more devastating, with $55 \%$ bare ground as compared to $25 \%$ on the nonimpacted range. Observations indicated that 32 trips also removed some plant bases sufficiently to not be recognized as plant cover.

\section{7}

There were no statistically significant differences in bare ground related to months of impact, nor were there any significant differences in 1977 between no impact, 2-trip impact, and 8-trip impact. The 32-trip impact had 2-5\% more bare ground than the other treatments, including the nonimpacted.

Growth of, and contribution of mulch from, nonimpacted plants adjacent to the relatively narrow ORV tracks appeared to be a factor in reducing bare ground in 1977.

\section{Photographic Imagery}

1976

Ground photography (color and color infrared, at $9.1 \mathrm{~m}$ from camera to ground point centered in image) was more sensitive to impacts on vegetation than was aerial photography. Uphill and downhill travel were distinguishable with ground photography. The impacts were more clearly distinguished with ground photography when the vegetation was lying a way from the camera than when it was lying toward the camera. The 8-trip and 32-trip treatments remained distinguishable throughout the season, but the 2-trip treatments were not clearly visible for all the sampling dates.

Aerial photography at the 1:5000 scale (scales tested were 1:3000 to 1:12,000) allowed identification of all 8-trip and 32-trip treatments, but not all the 2-trip treatments.

In both ground and aerial photography, the color infrared film was superior in May, June, and July when the vegetation was actively growing. The color film was superior in August and September when the bulk of the vegetation was dry.

It was concluded that for season long use, color was the best film to use for ground photography. It is recommended that for aerial photography, color infrared be used when vegetation is green and color used when most of the vegetation has dried. Using one film or the other for season long use is not recommended.

\section{$1977-1978$}

Ground photography in 1977 clearly showed residual wheel tracks and/or damage to sagebrush in $80-85 \%$ of the 8-trip and 32-trip treatments photos. Visual evidence of residual damage in the 2-trip treatment was seen in $15 \%$ or fewer of the ground photos. Soil rutting was still evident only in the June 32-trip treatment. Carryover visual evidence of impact was greatest in the previous year's May and June impacts and least in the September impacts.

All treatments but the 2-trip were easily identified on color infrared aerial photos taken in June. When aerially photographed near the end of July, the ORV tracks were about equally, but somewhat less easily, recognizable on the color infrared and color photos. The tracks were easily recognizable again in late August aerial photography with color film, but not so easily with color infrared film.

Aerial photography was repeated in June, 1978, with color infrared film. Four 32-trip treatments, May through August, and three 8-trip treatments, were still evident. Two-trip treatments could not be identified.

Obviously, the photographic evidence presented us with a dilemma. Canopy cover data showed essentially no carry-over effect of ORV impacts into 1977 on vegetation except for the 32-trip treatments, and even those were slight; yet, the photographic evidence showed a definite carry-over of impacts. Our only conclusion can be that the canopy cover method of vegetational analysis as we used it was not entirely adequate for the task. Further studies should focus on more refined photography and more sophisticated quantification of imagery characteristics.

\section{Practical Implications}

There clearly is no significant damage beyond the first year to living plants (except shrubs as noted above) by vehicles traveling up to eight times on the same tracks. This conclusion assumes that soils are not wet enough to be rutted by vehicles. There is increasing likelihood of damage carrying over into subsequent years as the number of trips in the same track goes above 8 . Until vegetation 
has dried, or cured, drivers should be encouraged not to follow other tracks. Wet soils should not be driven on at all.

The situation changes markedly after the vegetation, particularly grass, has dried. Breakage of standing vegetation reserved for winter grazing becomes a significant factor. It is estimated that 1 or 2 trips over the same track with the type of vehicle and tires used in this study will cause a loss of $.06-.12$ acres of cured vegetation per mile of travel. The maximum loss of cured vegetation may be as much as 0.18 acres per mile for as many as 8 trips on the same track. This is essentially total loss of cured vegetation and additional trips are of little consequence in this respect.

It appears that the most practical recommendaton after forage has dried is to minimize the number of new tracks made on a range being reserved for winter use. Therefore, drivers should be encouraged to follow existing tracks and roads rather than making new tracks. If the range is not being reserved for winter use, then the drivers should be encouraged to not follow other tracks.

\section{Literature Cited}

Daubenmire, R. 1959. A canopy-coverage method of vegetational analysis Northw. Sci. 33:43-64.
Dotzenko, A.D., N.T. Papamichos, and D.S. Romine. 1967. Effect of recreational use on soil and moisture conditions in Rocky Mountain National Park. J. Soil Water Conserv. 22:196-197.

Hill, R.R., and F. Lee Kirby. 1948. Treadruts lead to gullies. Colorado Conserv. Comments 10:11-12.

Liddle, M.J., and P. Greig-Smith. 1975. A survey of tracks and paths in a sand dune ecosystem. J. Appl. Ecol. 12:893-930.

McLeod, H.E. 1966. Draft, power efficiency, and soil composition characteristics of single, dual, and low pressure tires. Trans. ASAE 9:41-44.

Philip, J.R. 1957. The theory of infiltration: 4. Sorptivity and algebraic infiltration equations. Soil Sci. 84:257-264.

Philip, J.R. 1958. The theory of infiltration: 7. Capillary potential which operated as a wetting front. Soil Sci. 85:333-337.

Richards, L.A. 1969. Diagnosis and improvement of saline and alkali soils. USDA Handb. 60.

Taylor, J.E., W.C. Leininger, and R.J. Fuchs. 1975. Baseline vegetational studies near Colstrip. Fort Union Coal Field Sympos. 5:537-551.

Vanden Berg, G.E., A.W. Cooper, A.E. Erickson, and W.M. Carleton. 1957. Soil pressure distribution under tractor and implement traffic. Agr. Eng. 38:854-855, 899. 